\title{
The role of chronic pain and suffering in contemporary society
}

Tidsskrift for Forskning i Sygdom og Samfund

Nr. 13, 2010 


\title{
Tidsskrift for Forskning i Sygdom og Samfund
}

\author{
Nr. 13: The role of chronic pain and suffering in contemporary society \\ (C) 2010 forfatterne og udgiverne.
}

Redaktion:

Mette Bech Risør (ansv.), Forskningsklinikken for Funktionelle Lidelser, Århus Sygehus

Torsten Risør, Forskningsenheden for Almen Praksis, Aarhus Universitet

Gitte Wind, VIA University College, Århus

Lotte Meinert, Institut for Antropologi og Etnografi, Aarhus Universitet

Peter Vedsted, Forskningsenheden for Almen Praksis, Aarhus Universitet

Ann Dorrit Guassora, Forskningsenheden for Almen Praksis, Københavns Universitet

Susanne Reventlow, Forskningsenheden for Almen Praksis, Københavns Universitet

Gxsteredaktør:

Marie Østergaard Møller, Department of Political Science, Aarhus University

Lise Kirstine Gormsen, Danish Pain Research Center, Aarhus University Hospital

Peer review foretages af et tværvidenskabeligt panel bestående af bl.a. læger, antropologer, filosoffer, historikere, psykologer, politologer og sociologer.

Proof: Thomas Christian Mikkelsen.

Layout og prepress: Jens Kirkeby, Aarhus Universitet \& Thomas Christian Mikkelsen.

Tryk: Werks Offset, Højbjerg.

Udgiver:

Foreningen Medicinsk Antropologisk Forum,

Afd. for Antropologi og Etnografi, Aarhus Universitet, Moesgård, 8270 Højbjerg.

Bestilling, abonnement, henvendelser og hjemmeside:

Tidsskrift for Forskning i Sygdom og Samfund.

Afd. for Antropologi og Etnografi, Aarhus Universitet, Moesgård, 8270 Højbjerg

Torsdag kl. 9-12, tlf. 89424597, email: sygdomogsamfund@hum.au.dk

www.sygdomogsamfund.dk

ojs.statsbiblioteket.dk/index.php/sygdomogsamfund/index

ISSN: 1604-3405

Tidsskriftet er udgivet med støtte fra Forskningsrådet for Kultur og Kommunikation.

Formål:

Tidsskrift for Forskning i Sygdom og Samfund er et tværfagligt tidsskrift, der tager udgangspunkt i medicinsk antropologi. Tidsskriftet har til formål at fremme og udvikle den forskning, der ligger i grænsefeltet mellem sundhedsvidenskab og humaniora/samfundsvidenskab. Tidsskriftets målsætning er at fungere som et forum, hvor disse fag kan mødes og inspirere hinanden - epistemologisk, metodisk og teoretisk - i forskellige forskningssammenhænge. Tidsskriftet formidler den debat og teoretiske udvikling, der foregår i de voksende faglige samarbejds- og forskningsinitiativer, der udspringer af dette grænsefelt. Tidsskriftet henvender sig til alle med interesse for forskning i sygdom og samfund og i særlig grad til sundhedsmedarbejdere i forsknings- og undervisningssammenhæng med forbindelse til tværfaglige miljøer.

Aims and scopes

The Journal for Research in Sickness and Society is an interdisciplinary journal which has a theoretical background in medical anthropology. The aim and purpose of the journal is to promote and develop research in the borderland between the health sciences and the humanities/the social sciences. The goal of the journal is to function as a forum in which these disciplines may meet and inspire each other epistemologically, methodologically and theoretically. The journal conveys the debate and theoretical development which takes place in the growing collaboration and research initiatives emerging from this borderland. The journal addresses all with an interest in research in sickness and society and especially health professionals working with education and/or research in interdisciplinary institutions. 


\section{Contents}

Marie Østergaard Møller \& Lise Kirstine Gormsen

Introduction 5

Peter Conrad \& Vanessa Lopes Muñoz

The medicalization of chronic pain 13

Lise Kirstine Gormsen

Pain as an object of research, treatment, and decision-making 25

Marie Østergaard Møller

Stereotyped perceptions of chronic pain 33

Claus D. Hansen

Making a virtue of sickness presence - reflections on the necessities of everyday workplace 'suffering' 69

Jane Ege Møller

Lack of motivation as suffering 89

Keld Thorgaard

The normative and epistemological status of pain experiences in modern health care 109

Anders Dræby Sørensen

The paradox of modern suffering 131

Lars Thorup Larsen

The circular structure of policy failure and learning 161

Abstracts på dansk 195

Authors 201

Vejledning til bidrag 205

Beskrivelse af nummer 14208 


\section{Pain as an object of research, treatment, and decision-making}

\section{Lise Kirstine Gormsen}

Danish Pain Research Center, Aarhus University Hospital lise.gormsen@ki.au.dk

Gormsen, L.K. (2010). Pain as an object of research, treatment, and decision-making. Tidsskrift for Forskning i Sygdom og Samfund, nr. 13, 25-32.

This essay is a reflection on my professional norms when I do pain research, treat pain patients, and communicate with the social system. Being both a medical doctor and a clinical researcher, I daily have to combine what I see as arbitrary rationalities in my approach to pain. The reason is that pain research is often conducted within a theoretical framework that mainly understands pain as a physical or biomedical phenomenon even though a broader and more precise perspective on pain exists - and is often used when physicians treat patients. It is of interest to see how easily doctors use different concepts of pain when they conduct biomedical research with advanced equipment and standardized tools with one hand, and with the other hand talk to patients, trying to focus on their needs and helping them cope with their pain using a very broad perceptive of pain. This dilemma of acting both as a researcher and a clinical doctor is not often discussed or reflected upon by doctors. An explanation could be the focus on productivity and efficiency that rules the everyday life of most doctors as opposed to a focus on reflection, concepts, and values in pain medicine. The focus of this essay is therefore to describe, reflect, and elaborate on the differences of pain as an object of research, 
treatment, and decision-making. In other words, to reflect upon the ambiguous practice doctors engage in when doing pain research and treating chronic pain patients. Furthermore, this essay may contribute to our understanding of why decisions on eligibility in the social system are made without adequate documentation of patients' chronic pain conditions.

When a person is unable to work because of chronic pain, the social system is contacted for economic and social support. The entitlement decision is divided between different fields of expertise with different views on the condition. The social worker, who acts as a gatekeeper, gathers information from experts in order to determine the entitlement and make the final decision. In general, the idea behind this practice is a very broad perspective on chronic pain including social, psychological, and biomedical elements. Doctors and pain experts share the same view to some extent; however, the social worker often requests strong biomedical evidence of a condition from the experts because their documentation tools favor objective measures. In other words, the broad perspective does not have the same legitimacy as the traditional biomedical view of pain among social workers administering public services (Østergaard 2005, 2009; Mik-Meyer, 2003). The basic problem is that this evidence is obtained through biomedical methods, and these objective methods can in many cases not adequately describe and explain the painful condition. Certain pain types, e.g., musculoskeletal pain, as seen in fibromyalgia, are not easily captured by standardized biomedical methods. Patients with fibromyalgia are undoubtedly suffering from pain, but there are no clear objective measures, and therefore the disorder is often described by health care professionals and social workers from a broad perspective including psychological and sociological as well as biological parameters. Nevertheless, the problem with approaching chronic - often also contested - pain from a broad perspective that is not rooted in biomedicine is that it is difficult to operationalize when studying pain and deciding the eligibility to social support, treatments, and other health care benefits for the pain patient. The weakness of this approach is that it does not lead to clear answers, and, in the case of chronic pain patients, they may therefore be seen as malingering. In other words, their conditions are described in terms that may not fully reflect the type of pain they suffer from.

To exemplify my point I will shortly outline my different practices. As a researcher I have conducted a project that measured pain, anxiety, and depression in patients with fibromyalgia (Gormsen, 2009, 2010). The pain was assessed by measuring pain thresholds to pressure and cold (Ahles et al., 1991; Gormsen, 2004; Arnold et al., 2008). The pain thresholds were measured on the skin with a small 
pressure device. The patients had to identify when they felt pain and when they could not tolerate more pain. The patients were also asked to put their hand into a cold water bath until they reached their tolerance limit. Our hypothesis was that patients with fibromyalgia have higher depression and anxiety scores and lower pain thresholds than healthy volunteers because pain, anxiety, and depression affect the same neurotransmitter systems; pain may thus cause depression and anxiety, and depression may cause pain and low pain thresholds. Fig. 1 (McMahon \& Koltzenburg, 2006) illustrates the complexity and interactions that shape the pain experience.

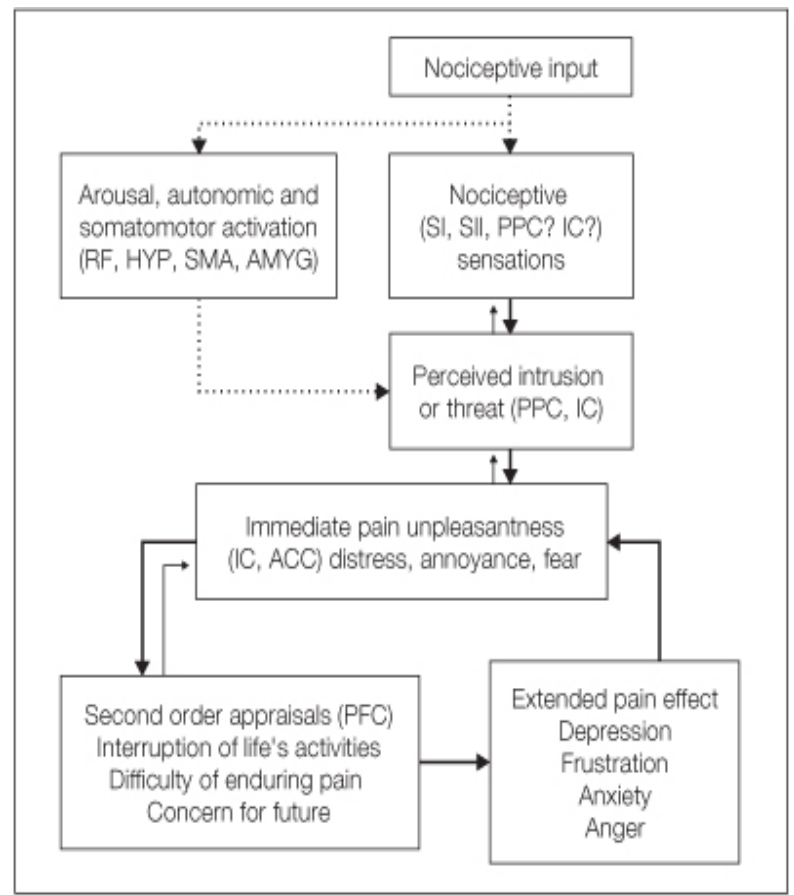

(c) Elsevier 2006. McMahon \& Koltzenburg: Wall and Melzack's Textbook of Pain 5e - www.textbookofpain.com

After the experiment I informed the patients about the results. Patients with fibromyalgia often have low pain thresholds, although still within the normal range, and high scores on depression and anxiety, without having a diagnosis of depression or anxiety. Afterwards, I focused on how the patients live and cope with their pain. One patient explained that it hurt continuously and she wished it would go away. She had, however, adjusted her life in such a way that she could function with her part-time job and family. The pain intensity was unchanged, but she had managed to integrate it into her life and she felt much better than 
before. She often felt, however, that she could not fulfil her ambitions as a mother and wife. For example, she could not pick her children up when they were crying because of the pain, and she was often too tired to engage in sexual activity with her husband. Furthermore, her main hobby was dancing, but the pain had taken that away from her. She had lost this part of her identity and social life. We then discussed the possible treatments of her pain. Medical treatment is a possibility, but that had not worked for her before, so non-pharmacological treatments including moderate excise, deep relaxation, and self-hypnosis were suggested. The latter are still seen as alternative treatments by the medical profession; however, more studies on these treatments are ongoing. As for her identity and social isolation, I explained to her that being active physically, sexually, and socially, for example by dancing, may ease the pain. She agreed to think about my suggestions.

The following morning I got a telephone call from the patient's social worker who had the patient in her office. The patient claimed that I had measured and verified her pain. I confirmed that the patient had participated in the study and repeated the results. The social worker asked if I were saying that she had a normal test. I tried to explain the theoretical framework. The social worker was friendly and said that she understood what I meant, but it would be very helpful if I had some test results that could place our client outside the normal range or something else that could verify her pain. I replied that no such test exists, but what I could do was a write a letter stating the test results and describing the theory about fibromyalgia, which supported that the patient had fibromyalgia, not a mental disorder, and that she was in fact in pain.

The basic problem is that multifaceted pain concepts are in play in the pain field. When I am doing research, it is based on a biomedical idea of pain with a positivistic approach to pain where objective natural science methods are used for human beings. This perspective includes broad perspectives on pain, also taking into account helplessness, frustration, anxiety, depression, etc. in the patient (Fig. 1), but it is converted into a simple experimental setting of measuring pain thresholds. In this way, the research project holds two biomedical ideas of pain. First, the broad biomedical idea illustrated in Fig. 1 including the psychological elements anxiety and depression, and then the simple biomedical or physical idea where Fig. 1 is operationalized into pain thresholds. Furthermore, when I am working as a pain doctor, the doctor-patient consultation represents a very broad idea of pain that focuses not only on the physical elements, but also embraces concepts of identity, social relations, and isolation. I focus on how the patients cope and live with the pain to find a way for the patients to gain control of their life and pain. I 
also suggest different self-help treatments as a supplement to the traditional treatments, e.g., self-hypnosis or learning to strengthen the perception of their identity and breaking their social isolation, for example by resuming previous physical activities. This indicates that pain is not only a physical object, but also a mental and a social object influenced by biological, psychological, and social factors. Finally, in the communication between doctors and social workers, the physical idea of pain is often represented by pain thresholds even though both parties know and accept that there is more to pain than the physical part such as psychological and sociological parameters.

This essay's argument is that the demand for objective measurements by the scientific societies and the social system gives rise to negative views on and treatment options for chronic pain patients with contested diagnoses. In consequence, we may end up meeting suffering people with mistrust and disrespect. Therefore, the study of pain should not be reduced to a biomedical measure if it should be used in a clinical setting as a basis for treatment, and, further along this line, as a basis for social workers' decision on whether or not a person is disabled enough to receive a public service. Any successful pain treatment relies on a dialogue between the doctor, the social system, and the patient, and any intervention should therefore include an understanding of the patient's self-perception of his or her pain.

Having a medical science that disregards supplementary information about the carriers of the phenomenon and its setting may mean that researchers and doctors lose sight of the phenomenon they are trying to study and treat. Biomedical science is certainly essential for developing new drugs and methods for treatment, but if it shall continue to play a dominant role in treating pain, the discipline would benefit from paying more attention to what constitutes and generates pain by including a broader - and more precise - perspective on pain. This point has consequences for the treatment of these patients. If we only have a physical perspective on pain, we may forget that not only medical treatment is essential for chronic pain patients.

The broad perspective is, however, difficult to operationalize and document, although it would lead to a better understanding of chronic pain patients in the social system. This is an old and debated problem: How the humanities legitimate themselves compared to natural science. From my perspective, the debate is not useful because no contradiction exists (Kvale, 2004). All methods of describing the world have pros and cons and therefore both perspectives should be represented. The reason is that using only the physical idea of pain for decision-making in the 
social system may result in wrong decisions. First, it may give rise to inequality compared with other patient groups, e.g., patients with multiple sclerosis (Østergaard, 2009), and second, a whole patient group could mistakenly be dismissed as malingering, which may lead to a worsening of the patient's psychological and sociological situation. We therefore need to have a broad perspective on pain as well as the biomedical approach, but the biomedical understanding of pain should be restrained because we deal with physical and mental processes of human beings that are imbedded in a complex environment.

Pain reflects the body's ability to tolerate irritation, which also includes the psychological and social mechanisms controlling the sensitivity to irritation. Pain is thus a matter of both pure physiology, represented by the biomedical view, as well as pure psychology, i.e., a system of cognitive and emotional relations and social identity regulated by differences and similarities in identity, social class, perceptions of legitimacy, and material bases of living. Pain is also a sociocultural phenomenon that is bound to local contexts and different cultures even though it is a universally known experience (Kleinman et al., 1992). On this basis it has been discussed by Kleinman (1992) and Jackson (1994) and others that a person is embodied with affective, emotional, and social responses, which means that pain is not only a physical sensation but also an emotion in a social context.

Methods that can grasp a broader, and thus more precise, perspective would be a phenomenological approach where the person's perceptions are central (e.g., Honkasalo, 2000) or a hermeneutic approach that focuses on an interactive level. However, these approaches cannot stand alone. They have to be integrated in biomedicine, e.g., by method triangulation or by integrating different views on pain in the discussion and perspective sections of biomedical research. This is in this perspective necessary even though difficult since both biomedicine and the humanities often are reluctant to compromise with their research methods for the purpose of integrating different views of pain in pain research.

\section{Conclusion}

Pain is a context-dependent physical, social, and mental phenomenon. Biomedical researchers often see pain as a physical object, and as such investigate it with biomedical methods. This perception is inaccurate as regards the essence of pain, and the misconception leads to a clinical pain medicine that does not capture the phenomenon it is studying and treating. This is the reason why doctors in 
contrast to researchers use a broader perspective on pain when treating chronic pain patients. By recognizing this, pain medicine is in a position to develop a research tradition that integrates different views and methods in pain medicine that will benefit the patient treatment and views of chronic pain patients in the social system and general public. Pain as an object of research, treatment, and decisionmaking reminds us that medicine and the problems it deals with have a special character. The philosopher Pellegrino described this special character of the field very precisely when he wrote that medicine is: 'The most human of sciences and the most scientific of humanities' (Pellegrino, 1979).

\section{Acknowledgements}

I would like to thank Marie Østergaard Møller and Marie Louise Tørring for our discussions about pain medicine, and Helle $\mathrm{O}$. Andersen for reading through my manuscript. This work has received no funding.

\section{References}

Ahles, T.A. et al. (1991). Psychiatric status of patients with primary fibromyalgia, patients with rheumatoid arthritis, and subjects without pain: a blind comparison of DSM-III diagnoses. American Journal of Psychiatry, 148, 1721-1726.

Arnold, B. S. et al. (2008). Affective pain modulation in fibromyalgia, somatoform pain disorder, back pain, and healthy controls. European Journal of Pain, 12, 329-338.

Gormsen, L. K. et al. (2004). Pain thresholds during and after treatment of severe depression with electroconvulsive therapy. European Journal of Pain, 8, 487-493.

Gormsen, L., Rosenberg, R., Bach, F. W., \& Jensen, T. S. (2010). Depression, anxiety, healthrelated quality of life and pain in patients with chronic fibromyalgia and neuropathic pain. European Journal of Pain, 14, 127.e1-8.

Gormsen, L., Rosenberg, R., Bach, F.W., \& Jensen, T.S. (2010). Differential pain modulation in patients with peripheral neuropathic pain versus fibromyalgia. Journal of Pain, submitted and under review.

Honkasalo, M. L. (2000). Chronic pain as a posture towards the world. Scandinavian Journal of Psychology, 41, 197-208.

Jackson, J. (1994). Chronic Pain and the Tension between the Body as Subject and Object. In T. J. Csordas (Ed.), Embodiment and Experience: The Existential Ground of Culture and Self (pp. 201-228). Cambridge: Cambridge University Press.

Kleinman, A. (1992). Pain and Resistance: The Delegitimation and Relegitimation of Local Worlds. In M.-J. DelVecchio Good, B. J. Good, P. E. Brodwin, \& A. Kleinman (Eds.), Pain as Human Experience: An Anthropological Perspective (pp. 169-97). Berkely: University of California Press.

Kvale, S. (2004). Interviews: An Introduction to Qualitative Research Interviewing. London: Sage Publications Ltd.. 
McMahon, S. B. \& Koltzenburg, M. (Eds.) (2006). Wall and Melzack's Textbook of Pain, $5^{\text {th }}$ Ed. Edinburgh: Churchill Livingstone.

Mik-Meyer, N. (2003). Anne er sygdomsfikseret. Forhandling af en institutionel diagnose. In: M. Järvinen \& N. Mik-Meyer (Eds.). At skabe en klient. Institutionelle identiteter i socialt arbejde. København: Hans Reitzels Forlag.

Pellegrino, E. D. (1979). Humanism and the Physician. Knoxville: The University of Tennessee Press.

Østergaard, M. M. (2005). Visitationsveje for en kronisk smerteramt med ledighed som problem: Et casestudie $i$ Viborg amt af visitationsnormer og kategoriseringsprincipper $i$ sundhedsvæsnet og $i$ det sociale system. Viborg: Trykkeriet i Sundhedsforvaltningen, Viborg Amt.

Østergaard, M. M. (2009). Hvad betyder smertetype for kategoriseringspraksis $i$ det sociale system? Viborg: Region Midtjylland.

Figure 1. Reprinted from Wall and Melzack's Textbook of Pain 5e, chapter 16: Bond, M., Psychiatric Disorders and Pain, p. 259, with permission from Elsevier and IASP Press. 